Imam Hanafi ${ }^{1}$

\title{
GAYA PENGAMBILAN KEPUTUSAN KEPALA SEKOLAH DASAR DITINJAU RASIONAL DAN INTUITIF
}

\begin{abstract}
Abstrak
Penelitian ini bertujuan untuk mengetahui gaya pengambilan keputusan yaitu rasional dan intuitif kepala sekolah. Penelitian ini menggunakan metode deskriptif kuantitatif. Sampel penelitian ini adalah 104 persepsi guru dalam melihat pengambilan keputusan kepala sekolah. Hasil penelitian ini menunjukkan gaya pengambilan keputusan rasional memperoleh persepsi $76,92 \%$. Gaya pengambilan keputusan intuitif memperoleh persepsi $21,15 \%$. Temuan ini menunjukkan ada perbedaan sangat signifikan gaya pengambilan keputusan rasional dengan gaya pengambilan keputusan intuisi dengan $\mathrm{p}=0,00(\mathrm{p}<0,01)$.
\end{abstract}

Kata Kunci: Kepemimpinan, Pengambilan Keputusan, Tipe Kepribadian

\begin{abstract}
This study aims to determine the style of decision-making that is rational and intuitive in terms of personality types. This study uses descriptive quantitative. The sample was 104 teachers perception to the principal. The results of this study demonstrate a rational decision-making style get teachers perception $76,92 \%$. gained $p=0.00(p<0.01)$. While the intuitive decisionmaking style with get perception 21,15 . These findings suggest there is a significant difference in rational decision-making styles with intuitif decision making style among principal with $\mathrm{p}=$ $0.00(\mathrm{p}<0.01)$.
\end{abstract}

Keywords: Leader, Decision Making, Type Of Personality.

\footnotetext{
${ }^{1}$ Prodi Pendidikan Guru Sekolah Dasar, Fakultas Ilmu Pendidikan, Universitas Pahlawan Tuanku Tambusai

Alamat email imamhanafimpd91@gmail.com
} 


\section{PENDAHULUAN}

Setiap pemimpin selalu dihadapkan pada situasi pengambilan keputusan, baik yang rutin ataupun tidak, yang dapat diprediksi ataupun tidak, yang sulit ataupun tidak, semua itu dihadapakan kepada tanggung jawab seorang pemimpin dalam hal ini kepala sekolah untuk mengambil keputusan.

Pengambilan keputusan ditandai dengan adanya ketidak sesuaian antara harapan dengan kenyataan yang disebut dengan masalah yang kemudian memerlukan alternatif-alternatif untuk pemecahannya. Dalam menentukan pilihan alternative yang diambil maka pemimpin harus melakukan pertimbangan dan analisis terhadap serangkaian alternatif tersebut. Alternatif yang mendatangkan manfaat dan menghindarkan diri dari kerugian-kerugian akan diambil, sementara alternatif yang merugikan akan dihindari atau diabaikan.

Proses pemilihan atau penentuan alternatif pemecahan masalah terhadap beberapa alternatif yang ada merupakan inti dari proses pengambilan keputusan. Ini berarti pengambilan keputusan bukan hanya tindakan sederhana memilih diantara alternatif. Pengambilan keputusan merupakan suatu proses mulai dari pengenalan masalah sampai dengan menerapkan keputusan kedalam suatu tindakan.

Pengambilan keputusan merupakan hal yang penting terutama bagi seorang pemimpin dalam suatu organisasi. Pemimpin pada semua tingkatan dan semua area di organisasi pasti akan membuat keputusan.

Sebagai contoh pimpinan tingkat atas akan membuat keputusan mengenai tujuan organisasinya, pimpinan tingkat menengah dan bawah akan membuat jadwal produksi, masalah kualitas produksi, kenaikan gaji, disiplin pegawai. Faktanya hampir semua pimpinan baik pimpinan tingkat atas, menengah maupun bawah mengambil suatu keputusan, baik keputusan yang bersifat rutin maupun keputusan yang kompleks. Oleh karenanya pengambilan keputusan merupakan inti pemimpin. Pengelola pada saat merencanakan, mengorganisir, memimpin dan mengendalikan disebut pengambil keputusan (Robbin \& Coulter, 2010).

Pemimpin di semua jenis organisasi menghadapi jenis masalah dan keputusan yang berbeda pada saat mereka melakukan pekerjaannya. Beberapa masalah bersifat langsung, tujuan pengambilan keputusan sudah jelas, masalah sering dihadapi dan informasi mengenai masalah mudah didefinisikan serta diselesaikan. Namun banyak situasi yang dihadapi organisasi melibatkan masalah tidak terstruktur, tidak jelas atau tidak lengkap. Selain itu ketika membuat keputusan pemimpin mungkin menghadapi kondisi yang berbeda. Robbin \& Coulter (2010) membedakan kondisi pengambilan keputusan yang berbeda kepastian, risiko, ketidakpastian. Kepastian yaitu situasi dimana pemimpin dapat membuat keputusan yang akurat karena hasil dari setiap alternative sudah diketahui. Risiko kondisi dimana pengambil keputusan dapat mengestimasi kemungkinan hasil yang pasti.

Ketidakpastian bila menghadapi sebuah keputusan yang tidak pasti mengenai hasilnya dan bahkan tidak bias mengestimasi probabilitasnya yang masuk akal. Situasi yang dihadapi ketika mengambil keputusan akan mempengaruhi metode pengambilan keputusan yang dipakai. Tepat tidaknya mengunakan suatu metode pengambil keputusan akan berpengaruh pada hasil keputusan itu sendiri. Setiap pengambilan keputusan mempunyai konsekuensi tertentu. Keputusan yang kurang tepat akan membawa dampak jangka panjang maupun jangka pendek. Bahkan juga menyebabkan kerugian berupa materi ataupun yang lainnya.

Pada situasi yang pasti dengan resiko yang bisa diprediksi seorang pemimpin cenderung mengunakan pendekatan rasional dalam mengambil keputusan, namun pada situasi yang tidak pasti pemimpin cenderung mengunakan intuisinya. 
Selain dipengaruhi oleh jenis masalah, kondisi, pendekatan, dalam pengambilan keputusan juga dipengaruhi oleh gaya pengambilan keputusan. Seorang pemimpin mungkin mengunakan gaya yang berbeda dengan pemimpin lainnya ketika mengambil keputusan. Beberapa pemimpin mungkin mengunakan waktunya untuk menimbang alternatif dan mengandalkan bagaimana mereka merasakannya, bergantung pada intuisi, sementara yang lain mungkin mengandalkan data eksternal sebelum membuat keputusan yang logis. Hal ini tidak membuat pendekatan yang satu lebih baik dari yang lainnya. Ini hanya merupakan gaya pembuatan keputusan mereka yang berbeda.

Dalam hal pengambilan keputusan ditemukan bahwa tidak semua individu melakukan pendekatan dengan cara yang sama dalam mengambil keputusan. Jadi ada gaya yang berbedabeda dalam pengambilan keputusan Perbedaan individu mempengaruhi perspektif dan tujuan pemecahan masalah. Perbedaan ini dapat digunakan untuk mengidentifikasi teknik pemecahan masalah yang tepat digunakan dalam setiap langkah dari proses pemecahan masalah. Proses pengambilan keputusan memungkinkan individu untuk menggunakan metode standar dalam berbagai situasi dan beradaptasi untuk memenuhi preferensi pribadi. Keputusan yang dibuat dengan cara ini lebih cenderung berlaku sejak individu sadar dapat mengenali baik kekuatan dan kelemahan pribadi.

Gaya pengambilan keputusan juga dipengaruhi oleh strategi pengambilan keputusan, apakah ia mengunakan strategi pengambilan keputusan yang bersifat rasional atau mengunakan strategi pengambilan keputusan yang bersifat emosional. Selain itu cara individu dalam menangapi informasi apakah ia mengunakan pilihan yang bersifat logis dan konsiten serta memaksimalkan nilai, atau berdasarkan pengalaman, perasaan dan akumulasi pertimbangan. Orientasi seseorang dalam mengambil keputusan juga dapat mempengaruhi gaya pengambilan keputusan. Apakah ia berorientasi pada hubungan atau berorientasi pada tugas. Black \& Montain (1984).

Berkaitan dengan gaya pengambilan keputusan Scott \& Bruce (1995), Harren (1980) dalam penelitiannya menemukan ada lima gaya pengambilan keputusan yang berbeda yaitu, rasional, intuitif, spontaneous, avoidance, dependent. Gaya pengambilan rasional ditandai dengan pencarian yang komprehensi untuk informasi, invetarisasi, adanya alternatif dan evaluasi alternatif secara logis. Gaya pengambilan keputusan intuitif ditandai perhatian pada perincian aliran informasi daripada pengolahan dan pencarian informasi secara sistematis, serta lebih mengandalkan firasat dan perasaan. Gaya spontaneous ditandai dengan keinginan untuk dapat mengambil keputusan secepat mungkin, Gaya dependent ditandai dengan pencarian saran dan masukan dari orang lain sebelum mengambil keputusan yang penting. Gaya Avoidance upaya untuk menghindari pengambilan keputusan kapan dimungkinkan.

Gaya pengambilan keputusan biasanya khas dan berbeda antara individu yang satu dengan yang lainnya. Gaya pengambilan keputusan dipengaruhi oleh perbedaan individu salah satunya kepribadian. Tipe orang yang orang yang panic-striken akan mengambil keputusan dengan cepat tanpa pertimbangan, tipe impulsive mengambil keputusan pada saat tertentu tanpa pertimbangan, hal ini berbeda dengan orang yang extravet dan memiliki emosi yang stabil tidak kesulitan dalam mengambil keputusan.

Pembahasan mengenai kepribadian sudah sejak lama dilakukan oleh para ahli. Kepribadian merupakan masalah yang kompleks sehingga seringkali menimbulkan perdebatan. Bahkan sampai sekarang batasan formal personality yang mendapat pengakuan dan kesepakatan luas di lingkungan ahli kepribadian belum ada. Namun diantara perbedaan definisi ada persamaan yang menjadi ciri bahwa definisi itu adalah definisi kepribadian. Kepribadian bersifat 
unik, khas, berjangka lama, bersifat kesatuan, bisa berfungsi baik atau berfungsi buruk (Allport dalam Sahrah, 1990). Selain itu Jung juga mengembangkan tipologi kepribadian yang kemudian sangat popular yaitu tipe extravett dan introvert.

\section{METODE}

Penelitian ini merupakan penelitian deskriptif kuantitatif dan komparatif. Populasi sebayak 322 guru kemudian pengambilan sampel ini akan dilakukan dengan menggunakan teknik statified proportional random sampling. Melalui teknik ini diperoleh sampel yang mewakili populasi secara proporsional, sesuai dengan proporsi setiap kelompok dalam strata populasi. Besar sampelnya ditentukan dengan mengikuti rumus Cochran (1991). Sampel penelitan ini berjumlah sekitar 104 guru yang yang dijadikan responden untuk melihat persepsi mereka tentang pengambilan keputusan kepala sekolah dengan rincian jenis kelamin pria atau wanita da status PNS atau Non-PNS.

\section{HASIL DAN PEMBAHASAN}

Skala gaya pengambilan keputusan berisi 50 butir. Skala ini mengandunga item-aitem yang mengungkap baik gaya pengambilan keputusan rasional maupun intuitif. Item yang mengungkap gaya pengambilan keputusan rasional terdiri dari 18 item sedangkan item yang mengungkap gaya pengambilan intuitif terdiri dari 32 item.

Skor dari masing-masing item baik item gaya pengambilan keputusan rasional maupun gaya pengambilan keputusan intuitif bergerak dari skor yang terendah 0 (nol) dan skor yang tertinggi 3 (tiga) dengan demikian dapat diketahui skor total minimum yang dimiliki masingmasing subyek kelompok gaya pengambilan keputusan rasional 0 dan skor total maksimum 57. Sedangkan skor total minimum yang dimiliki masing-masing subyek kelompok gaya pengambilan keputusan intuitif 0 dan skor total maksimum 92.

Berdasarkan perhitungan total skor jawaban yang diberikan kepada subyek diketahui bahwa sebanyak 46 atau 44,23\% memiliki gaya pengambilan keputusan rasional sangat tinggi, 34 atau 32,69\% subyek penelitian memiliki gaya pengambilan keputusan rasional tinggi, 20 atau $19,23 \%$ memiliki gaya pengambilan keputusan rasional cukup.

Ini menunjukkan lebih dari $76,92 \%$ subyek penelitian cenderung mengunakan gaya pengambilan keputusan rasional dalam memutuskan permasalahan yang dihadapinya, baik permasalahan yang berhubungan dengan pekerjaan maupun dalam kehidupannya. Subyek penelitian memilih mengunakan sumber informasi eksternal seperti saran, pertimbangan dari orang lain, juga data dan fakta empiris sebagai dasar pengambilan keputusan. Cara mengelola informasi mereka memilih mengunakan pertimbangan logis, obyektif, sistematis dan mempertimbangkan resiko dari setiap alternative keputusan yang akan diambil. Dari 104 guru yang memberikan persepsinya terhadap 19 kepala sekolah maka hanya 2 orang guru yang memberikan persepsi kepala sekolah memiliki gaya pengambilan keputusan rasional rendah. Dalam penelitian ini juga ditemukan subyek penelitian yang memiliki gaya pengambilan keputusan intuitif hanya 2 atau 1,92\% subyek yang sangat tinggi, gaya pengambilan intuitif yang tinggi sebanyak 20 atau 19,23\% subyek. Sebanyak 34 atau 32,69\% subyek yang cukup, sebanyak 44 atau $42,30 \%$ subjek penelitian gaya pengambilan keputusan intuitifnya rendah. Ini 
berarti hanya $21,15 \%$ subyek penelitian yang mengandalkan intuisinya dalam mengambil keputusan, baik keputusan dalam pekerjaan maupun dalam kehidupan sehari-hari. Intuisi itu sendiri bersumber dari nilai atau etika budaya, pengalaman, perasaan atau emosi, pikiran bawah sadar, pengetahuan dan ketrampilan.

Nampak jelas bahwa sebagaian besar subyek penelitian cenderung mengunakan gaya pengambilan keputusan rasional. Untuk lebih jelasnya akan digambarkan dalam table berikut ini.

Penelitian ini memaparkan gaya pengambilan keputusan yang rasional dan intuitif, ini berarti penelitian ini mengambarkan hal yang menjadi keunikan individu kepala sekolah. Gaya pengambilan keputusan menunjukan perbedaan seseorang dalam suatu situasi tertentu. Hasil penelitian menunjukkan ada perbedaan yang sangat signifikan antara gaya pengambilan keputusan rasional dan intuitif.

Tabel 1. Distribusi Subyek Berdasarkan Gaya Pengambilan Keputusan

\begin{tabular}{ccccc}
\hline & \multicolumn{2}{c}{$\begin{array}{c}\text { Gaya Pengambilan Keputusan } \\
\text { Rasional }\end{array}$} & $\begin{array}{c}\text { Gaya Pengambilan Keputusan } \\
\text { Intuitif }\end{array}$ \\
\cline { 2 - 5 } & $\mathbf{N}$ & Prosentase (\%) & N & Prosentase (\%) \\
\hline Sangat Tinggi & 46 & $44,23 \%$ & 2 & $1,92 \%$ \\
Tinggi & 34 & $32,69 \%$ & 20 & $19,23 \%$ \\
Cukup & 20 & $19,23 \%$ & 34 & $32,69 \%$ \\
Rendah & 3 & $2,88 \%$ & 44 & $42,30 \%$ \\
Sangat & 1 & $0,96 \%$ & 4 & $3,84 \%$ \\
Rendah & 104 & $100 \%$ & 104 & $100 \%$ \\
Jumlah & 104 & & & \\
\hline
\end{tabular}

Kategori

Kepribadian bersifat khas dan unik, karena itu kepribadian dapat dipakai untuk menjelaskan sifat individu yang membedakan seseorang dengan orang lain, sehingga karakteristik seseorang yang berbeda akan memunculkan respon yang berbeda meskipun mereka berada pada situasi yang sama. Salah satunya ketika harus mengambil suatu keputusan, seorang pemimpin akan mengunakan gaya yang berbeda dengan pemimpin yang lain meskipun dihadapkan pada situasi yang hampir sama. Ada yang cenderung mengunakan pendekatan rasional dengan berdasarkan pada data dan fakta serta melakukan pendekatan sitematis. Namun ada juga yang lebih yakin dengan perasaan dan pengalamannya sehingga lebih memilih mengunakan pendekatan intuitif..

Penelitian ini mendukung penelitian yang terdahulu seperti yang dilakukan Evi Kurniasari (2012) tentang gaya pengambilan keputusan ditijau dari tipe kepribadian. Hasil penelitian menyatakan berbeda signifikan antara gaya pengambilan keputusan rasional dengan tipe DISC kepribadian, dan gaya pengambilan keputusan intuisi dengan tipe DISC kepribadan. Berikutnya penelitian oleh Kutandi (2004) menemukan ada perbedaan yang signifikan dalam gaya pengambilan keputusan rasional dan intuitif yang dilakukan oleh karyawan yang berkecenderungan tipe kepribadian ekstrovet dan introvert. Huitt menghubungkan dimensi kepribadian Myers-Briggs Type Indicator (MBTI) yang terdiri dari extravert, introvert, sensing, 
intuitive, thinking, feeling, judging, perceiving dengan pemecahan masalah dan pengambilan keputusan, ternyata ditemukan bahwa perbedaan dimensi kepribadian mempengaruhi perbedaan dalam orientasi pemecahan masalah, kriteria effektivitas dalam mengambil keputusan, proses dan pemilihan alternatif, juga teknik dan kekuatan.

\section{1. Gaya Pengambilan Keputusan Rasional}

Gaya pengambilan keputusan rasional biasanya dilakukan oleh pemimpin yang memiliki informasi yang cukup, sehingga ia bias menentukan keputusan yang rasional untuk organisasi yang ia pimpin. Dalam gaya pengambilan keputusan rasional informasi diolah secara sitematis, logis dan memperhitungkan resiko. Memilih mengunakan strategi yang logis dan mempertimbangkan resiko dalam mengambil keputusan.

\section{2. GAYA PENGAMBILAN KEPUTUSAN INTUITIF}

Gaya pengambilan keputusan intuitif biasanya dipakai ketika informasi yang tersedia terbatas, dihadapkan pada situasi yang baru atau tindakan yang tidak biasa. Dalam hal ini seseorang mengambil keputusan berdasarkan pengalaman yang terdahulu dan melibatkan perasaan dan emosi yang mendalam ketika mengambil keputusan.

\section{SIMPULAN}

Kesimpulan penelitian ini adalah:

1. Terdapat perbedaan yang signifikan antara gaya pengambilan keputusan kepala sekolah rasional dan intusi.

2. Gaya pengambilan keputusan kepala sekolah rasional memperolah persepsi $76,92 \%$

3. Gaya pengambilan keputusan kepala sekolah intusi memperoleh persepsi $21,15 \%$

4. Gaya pengambilan keputusan kepala sekolah rasional lebih tinggi dari pada intuisi.

\section{Daftar Pustaka}

Arroba, T., 1998, Decision Making ByChinese, Journal of Social Psychology, Vol. 38. 102-116

Birgham Young University. 1999. Career and Major: Decision Making. Utah: BirghamUniversity.

Evi Kurniasari. 2012. Pengambilan Gaya Keputusan Ditinjau Dari Tipe Kepribadian. Jurnal Psikostudia Universitas Mulawarman, Vol. 1, No. 1/Juni 2012, hlm. 60-80

Eysenck, H.J. \& Wilson, G. D. 1982. Know Your Own Personality. Anglesburg: Pelican Books, Hazel Watson and Viney, Ltd.

Harren, V.A. 1980. Assesment of Carrer Decision Making. Los Angelos:

Western Psychological services.

Huitt, S.A. 1992. Optimism/Pessimism. www.huitt.com.

Kutandi, H. 2004. Gaya Pengambilan Keputusan Ditinjau dari Tipe Kepribadian. Tesis. Yogyakarta: Fakultas Psikologi Yogyakarta

Robbins, S. P., 2010, Perilaku Manusia. Versi Bahasa Indonesia: Konsep, Kontroversi dan Aplikasi, Jakarta: PT. Prenhallindo

Sahrah, A. 1990. Model Interaksionisme dalam Pengukuran Psikologi kepribadian. Tesis. Tidak diterbitkan. Yogyakarta: Fakultas Psikologi, UGM.

Scott, S.G. \& Bruce, R.A., 1999. The

Moderating Effect of Decision Making Style on The Turnover Process: An 
Extention Of Previous Research, Suharman. 1999. Teori Prospek dalam

Pembuatan Keputusan dan Implikasinya. Anima: Media

Psikologi Indonesia. 14, 296-304.

Suryabrata, S. 1995. Psikologi Kepribadian. Jakarta: PT Raja Grafindo Persada 